\title{
A SÍNDROME DE ULISSES
}

Paula Beatriz Mitter Carvalho

\section{RESUMO}

"Síndrome de Ulisses" é o nome sob o qual Santiago Gamboa nos traz a estória de um jovem colombiano, chamado Esteban, que, indo a Paris a fim de tornar-se escritor e estudar literatura, acaba por nos apresentar ao mundo e à síndrome do imigrante. A partir daí, a nossa "viagem de Ulisses" será traçar caminhos de Paris a İtaca, da literatura à Psicanálise.

\section{ABSTRACT}

"Ulisses Syndrome" is the story in wich Santiago Gamboa brings us the tale of a young Colombian guy, called Esteban, whom, in going to Paris to become a writer and to study literature, ends up presenting to us the world and to the immigrant syndrome. From here, our "Ulysses journey" consists in tracing the way from Paris to Ítaca, from literature to Psychoanalysis.

O mito é o nada que é tudo. O mesmo sol que abre os céus É um mito brilhante e mudo -

O corpo morto de Deus, Vivo e desnudo.

Este, que aqui aportou, Foi por não ser existindo. Sem existir nos bastou. Por não ter vindo foi vindo E nos criou.

Assim a lenda se escorre A entrar na realidade, E a fecundá-la decorre. 
Em baixo, a vida, metade De nada, morre. ${ }^{1}$

"Síndrome de Ulisses" é o nome sob o qual Santiago Gamboa nos traz a estória de um jovem colombiano, chamado Esteban, que vai a Paris a fim de tornar-se escritor e estudar literatura e acaba por nos apresentar ao mundo e à síndrome do imigrante.

Esteban revezava-se entre dois empregos, dois mundos, entre dar aulas de espanhol a europeus no Langues dans le monde e "fazer a plonge" num restaurante coreano, o Les goelins de Pyongang. Enquanto naquele, seu sotaque colombiano tornou-se empecilho a que trabalhasse, diante daqueles que queriam aprender "o verdadeiro espanhol", nesse, chegara, principalmente, por "medo de não poder suportar a vida que escolhera e ter de voltar a Bogotá, derrotado"2.

Já disse que tinha graves problemas de auto-estima e que me considerava bem pouca coisa. Então fui até o mais baixo, que eram os trabalhos de lavagem e secagem de pratos em restaurantes, uma coisa nojenta que obrigava a ficar em contato com a gordura e os restos de comida, canecas e desperdícios devorados pelos micróbios, águas repletas de molhos e sucos ${ }^{3}$.

Ele, o narrador, não é como os demais estrangeiros, era um privilegiado, que poderia voltar à pátria, ao contrário da maioria, refugiados, exilados, ilegais, dissidentes e opositores, que "não podiam voltar".

(...) e ele insistiu, você vai passar, é uma pessoa instruída e com um diploma, e além disso provém de uma família de universitários. Aqui, neste porão parecia que éramos iguais, mas no fundo você é diferente. Os que nascemos embaixo geralmente permanecemos embaixo ${ }^{4}$.

1 PESSOA, Fernando. Mensagem; organização Fernando Cabral Martins. - São Paulo: Companhia das Letras, 1998. 1a. Parte. Brasão. II - Os Castelos. 1ํ: Ulisses. p. 23.

${ }^{2}$ GAMBOA, Santiago. A síndrome de Ulisses; tradução Luis Reyes Gil. - São Paulo: Editora Planeta do Brasil, 2006. p.54.

${ }^{3}$ GAMBOA, Santiago. A síndrome de Ulisses; tradução Luis Reyes Gil. - São Paulo: Editora Planeta do Brasil, 2006. p. 54.

${ }^{4}$ GAMBOA, Santiago. A síndrome de Ulisses; tradução Luis Reyes Gil. - São Paulo: Editora Planeta do Brasil, 2006. p.354.

Revista Brasileira de Direito Internacional, Curitiba, v.8, n.8, jul/dez.2008 
Palavras de seu colega de trabalho no Les goelins de Pyongang , Jung, que se nos apresenta:

Sou coreano, mas no sentido mais triste do termo, ou seja, "coreano do norte" (...) Fugi porque queria fazer com a minha vida o que me desse vontade (...) Depois casei com Min Lin (...) e tive uma filha. A menina morreu aos sete anos. Em vez de leite a mãe só podia lhe dar um mingau de fubá, o que ao final de um ano a deixou cega, por causa da avitaminose. O governo do pai de Kim Il Sung nos dava cinco quilos de arroz por mês, mas isso não era suficiente para crescer. Perdemos nossa filha, e minha esposa, Min Lin, se recusou a viver. Entrou em depressão e tentou suicidar-se. Engoliu uma bolsa de vidro moído e ficou no hospital por mais de quatro meses. Depois foi presa, porque na Coréia do Norte o suicídio é proibido (...) Foi então que decidi fugir do país (...) Eu a abandonara. A sobrevivência nos transforma em pessoas duras, sem coração ${ }^{5}$.

Jung, ainda, "foge" para Pequim, para a Bulgária, de onde vem para

Paris:

Tinha 400 dólares no bolso e uma maleta de papelão com uma camisa, uma foto da minha filha morta e uns sapatos furados. Voltei a pensar. Não vi nenhum espectro e senti que a minha vida, até então, havia sido uma longa fuga. $\mathrm{O}$ mundo fica pequeno quando não se tem casa $\mathrm{e}$ todos os países são hostis (...) Pensei, sou um pobre desgraçado e ninguém se importaria se eu cortasse os pulsos. E isso me deu força. Quando alguém é tão pouca coisa para os outros tende a se cuidar. Se tivesse sorte e me protegesse, quem sabe poderia voltar a viver alguma coisa boa. Um momento alegre, por exemplo. Ou deixar de ter medo. Já fazia seis anos que eu sentia medo. Qualquer dia uma mão poderia me pegar pelo ombro e me deter. Deixar de sentir medo, que coisa difícil. O bom ficou para trás. Sou um miserável, pois abandonei a única pessoa que gostava de mim. Não mereço nada, mas tampouco peço. Vou sobreviver um pouco mais, para ver o que acontece. E aqui estou eu, no segundo subsolo do Les goelins de Pyongang, pensando em Min Lin. Economizei alguma coisa para ela. Se a encontrar, vou trazê-la para cá. É a única coisa que me falta fazer, se é que ela não está morta ${ }^{6}$.

É Jung o sujeito de que trata o seguinte "diagnóstico" da Síndrome de

Ulisses:

${ }^{5}$ GAMBOA, Santiago. A síndrome de Ulisses; tradução Luis Reyes Gil. - São Paulo: Editora Planeta do Brasil, 2006. p.58-60.

${ }^{6}$ GAMBOA, Santiago. A síndrome de Ulisses; tradução Luis Reyes Gil. - São Paulo: Editora Planeta do Brasil, 2006. p.60-61.

Revista Brasileira de Direito Internacional, Curitiba, v.8, n.8, jul/dez.2008 
$\mathrm{O}$ que pode ter acontecido, doutor? perguntei para preencher aquele incômodo silêncio, e ele disse, ah, com os suicídios nunca se sabe, pelo que pude averiguar lendo sua ficha médica vi que era um homem solitário e sem documentos legais, com três hospitalizações recentes por ataques do tipo epiléptico, perda da consciência e do senso de realidade, dores abdominais e delírios. Num deles disse estar sendo atacado por pássaros... As coisas difíceis que deve ter vivido, sua auto-estima lá no chão, a sensação de estar indefeso e o medo, tudo isso deve tê-lo levado ao estresse crônico e à depressão. Tem uma doença muito relacionada com esses sintomas, disse o médico, mas não tinha nome. Ainda não havia sido batizada como síndrome do imigrante ou síndrome de Ulisses ${ }^{7}$.

Jung, antes, sequer, de ter notícias de Min Lin nos diz algo sobre a morte e o que poderia mantê-lo afastado dela: ser "tão pouca coisa para os outros":

Voltei a pensar. Não vi nenhum espectro e senti que a minha vida, até então, havia sido uma longa fuga. O mundo fica pequeno quando não se tem casa e todos os países são hostis (...) Pensei, sou um pobre desgraçado e ninguém se importaria se eu cortasse os pulsos. E isso me deu força. Quando alguém é tão pouca coisa para os outros tende a se cuidar (GAMBOA, p. 60).

Jung, de fato, "encontra" Min Lin, já nas últimas páginas do livro. Faz

dívida com o dono do restaurante em que trabalhava para pagar os "atravessadores” - "(...) chega sábado. Estão trazendo-a de avião de Seul, pois não foi preciso fazer trajetos por terra. Compraram um visto." (GAMBOA, p. 368). As aspas para "o encontro" devem-se ao suicídio de Jung, cometido às vésperas da chegada de Min Lin a Paris.

Podemos destacar, da estória narrada por Esteban, alguns pontos, certos "nós", que se repetem e se repetem. Ele mesmo nota algo neste sentido:

(...) Então tive uma modesta revelação, que foi o modo com que, às vezes, a realidade se apresenta em séries paralelas, assimiláveis a um mesmo sistema, o que podia chegar a ser um tanto monótono ${ }^{8}$.

\footnotetext{
${ }^{7}$ GAMBOA, Santiago. A síndrome de Ulisses; tradução Luis Reyes Gil. - São Paulo: Editora Planeta do Brasil, 2006. p.370.

${ }^{8}$ GAMBOA, Santiago. A síndrome de Ulisses; tradução Luis Reyes Gil. - São Paulo: Editora Planeta do Brasil, 2006. p.254.
}

Revista Brasileira de Direito Internacional, Curitiba, v.8, n.8, jul/dez.2008 
As mulheres e o relacionamento, na maioria das vezes, sexual, entre elas e Esteban, certamente, chama atenção e, provavelmente, desperta 0 pudor em quem o lê, mas, antes do sexo, são as personagens femininas os nós, francesas, latinas, africanas, turcas, eslavas, chinesas, prostitutas ou não... Esteban conhece muitas:

Agora que minha vida sexual havia se enriquecido, nada me atraía mais do que acrescentar outra marca na minha arma, entre outras coisas porque já começava a sentir aquela curiosidade dos imigrantes em relação às mulheres francesas ${ }^{9}$.

Ele, não raro, vê-se em conflito, dividido entre os vários mundos dessas mulheres, até que, indeciso diante daquela que dizia ser "seu grande amor", joga, momento em que, posso dizer, foram as duas únicas vezes em que seu nome: Esteban, foi-nos apresentado - pela boca de uma mulher (Esteban! Esteban!):

Então algo se iluminou na minha cabeça uma idéia ditada pelo desespero, e eu disse, desta vez sim vamos jogar com o amor, é o que vamos fazer. Vamos jogar até o fim. Peguei um baralho de cartas que tinha na mala e nunca usava, talvez esperando por aquela noite, e disse: quem tirar a carta mais alta decide, concorda? (...) É preciso arrumar isso de algum jeito e se vamos jogar roleta russa tem que ser com balas de verdade (...) lembre-se, sem palavras nem choro, a gente vai fazer o que esta carta mandar (...) Desvirei a carta, e ao fazê-lo, foi como se uma luz emergisse do centro do quarto ${ }^{10}$.

Ainda não havendo percebido essa questão das mulheres da e na estória, é fato que outros dois "nós" aos quais pretendemos fazer menção também nos chegam "via mulheres". São outros pontos centrais da narrativa o que se passa com outros dois emigrantes: Nestor, colombiano e Jung, coreano.

Nestor desperta a atenção do narrador durante uma partida de xadrez - xadrez, cartas, jogos...- entre ambos, disputada num torneio promovido na "sociedade de colombianos", em Paris, freqüentada por eles, cujo prêmio,

\footnotetext{
${ }^{9}$ GAMBOA, Santiago. A síndrome de Ulisses; tradução Luis Reyes Gil. - São Paulo: Editora Planeta do Brasil, 2006. p.93.

${ }^{10}$ GAMBOA, Santiago. A síndrome de Ulisses; tradução Luis Reyes Gil. - São Paulo: Editora Planeta do Brasil, 2006. p.367.
}

Revista Brasileira de Direito Internacional, Curitiba, v.8, n.8, jul/dez.2008 
conferido a Nestor, o vencedor, foi "sair da festa com Sophie" - quem ensinava francês aos colombianos. Durante sua derrota, Esteban nota em seu adversário alguém além do Nestor que todos conheciam, pacato, quieto, tímido, a ganhar a partida, com jogadas inesperadas, um Nestor de "olhar aterrador", "voz gélida" e "expressão desalmada e inumana":

Levantei o rosto, olhei-o nos olhos pela primeira vez e lhe disse, não há muito o que fazer, não é mesmo? Ele, com uns olhos nos quais julguei ver fogo ou lava ardente, respondeu, não, você não tem nada a fazer, absolutamente nada, mas foi uma boa partida. Essa última coisa ele acrescentou com uma voz estranha, como se o ar e suas palavras emergissem do fundo de uma gruta ${ }^{11}$.

Nestor desaparece após "a noite do prêmio"; Esteban, então, faz uma longa e profunda investigação para saber do paradeiro do enxadrista, de vida aparentemente pacata, mas que se mostra repleta de pequenos mistérios, até que o caso é, em partes, esclarecido:

(...) Sophie passou do meu lado e disse, vai no meu quarto porque este está ocupado, então fui até lá e observei a cama onde Nestor estivera sentado e o banheiro onde ela preparara o show. Nessa altura alguma coisa que estava na mesa de cabeceira me chamou poderosamente a atenção. Foi um porta-retrato com a foto de um jovem. Não me custou muito esforço reconhecer o mesmo rosto do recorte do France Soir. Era o jovem assassinado, o rapaz que agrediu Gastón e que Nestor destroçou na porrada. Foi isso o que ele viu antes de ir embora! Reconheceu a foto e se afastou, fugiu deste lugar e decidiu desaparecer... É o cadáver que emerge do passado, o corpo que flutua e o sinaliza (...) Sophie voltou a entrar no quarto e me viu olhando a foto, então eu falei, é o seu namorado? Ela, com expressão séria, respondeu, era meu irmão menor... Acharam-no morto, bateram nele até matá-lo e o deixaram na rua, como um cachorro. Nunca se soube quem foi, seu assassino deve estar solto ${ }^{12}$.

Além dessas séries que se cruzam na narrativa de Esteban mulheres, sexo, jogos, drogas, hospitais, colombianos, coreanos etc -, há algo sobre o que tudo se passa: Paris, a Paris "dos emigrantes", a Cidade, presente

${ }^{11}$ GAMBOA, Santiago. A síndrome de Ulisses; tradução Luis Reyes Gil. - São Paulo: Editora Planeta do Brasil, 2006. p.99.

${ }^{12}$ GAMBOA, Santiago. A síndrome de Ulisses; tradução Luis Reyes Gil. - São Paulo: Editora Planeta do Brasil, 2006. p.361.

Revista Brasileira de Direito Internacional, Curitiba, v.8, n.8, jul/dez.2008 
em suas ruas, praças, quartiers, a Paris habitada por fantasmas. Fantasmas, sim, de um inferno, de uma cidade outra à "Paris das luzes". Sentado num vagão do metrô, nosso aspirante a escritor, sobre Paris: "nesta cidade populosa e fantasmal onde nenhum de nós, na realidade, existia" (GAMBOA, p. 180). A diferença "entre mundos", entre "dimensões" diversas", o fosso entre as "Parises" é perceptível aqui:

Desci correndo as escadas e, ao empurrar o portão de entrada, a sensação da qual falei antes, aquela 'dimensão desconhecida', se fez ainda mais patente, pois um poderoso sol me cegou os olhos, um sol que nunca havia visto nesta cidade e que inundou minhas pupilas, ofuscando-as, e fiquei apavorado com a enorme atividade da rua, o barulho dos carros e o caminhar das pessoas que iam e vinham pelas calçadas, atarefadas, alheias ao que acontecia naquele diminuto espaço de não mais de 20 metros quadrados onde passara os últimos três dias da minha vida e que, visto de fora, pouco antes de descer pelas escadarias do metrô, ficou representando na minha avariada mente como um imenso ataúde repleto de fantasmas, um lugar afastado e remoto da realidade no qual, de qualquer modo, tinha passado umas horas estupendas ${ }^{13}$.

Nosso narrador não "pertencia" a essa Paris e sua volta, a viagem que dera ao ter recorrido a ela, talvez nos fique clara através da experiência "da descida" de seu colega de doutorado, o qual visita os esgotos de Paris como forma de viver "sua própria novela", a partir do personagem de seu autor favorito Adán Buenosayres, de Leopoldo Marechal:

(...) fui seguindo o fio do livro, aquela viagem de Ulisses em torno de uma cidade que tem um espelho ou um duplo subterrâneo, a cidade infernal, e se converte numa cidade alienada (...) um mundo embaixo da cidade, uma via helicoidal descendente com nove espirais onde estão os bairros (...) e que correspondem a círculos dantescos. Quis ter essa experiência ou alguma coisa parecida, amigo. Sei que Cortázar já falou dos subterrâneos de Paris e das escavações do metrô, mas para viver isso faltava algo concreto, então recorri a um amigo do meu tio, um argelino que percorre os esgotos de Paris recolhendo o que as pessoas atiram pelos bueiros (...) ele sempre nos contou histórias de objetos encontrados, armas de fogo ou navalhas que imediatamente entregam à polícia e geralmente têm a ver com crimes, ou então jóias, tudo aquilo que as mulheres tiram no banheiro e de vez em quando cai na privada e desaparece; pois na realidade não desaparece, fica ali

\footnotetext{
${ }^{13}$ GAMBOA, Santiago. A síndrome de Ulisses; tradução Luis Reyes Gil. - São Paulo: Editora Planeta do Brasil, 2006. p.168.
}

Revista Brasileira de Direito Internacional, Curitiba, v.8, n.8, jul/dez.2008 
misturado com a merda e a urina e todas as imundícies que a vida produz, e eles, essa equipe de africanos (...) correm esses caminhos subterrâneos (...) convivendo com ratos e baratas e inclusive serpentes e lagartos, se bem que raramente, e claro, imaginando, pelas coordenadas, onde se encontrariam se estivessem na superfície, que pode ser uma igreja ou o hotel Ritz ou a rua das putas e os sex shops de Saint Denis (...) consegui finalmente viver a descida de um modo real. Agora entendo melhor aquilo do espelho enterrado e da outra cidade e inclusive o do inconsciente. É verdade que existe uma zona de realidade onde são vividos os contrários, onde vai parar o vômito e o excremento daquelas belas mulheres e daqueles dândis que, em cima, na cidade solar, representam os ideais do mundo (...) e fiz anotações sobre minha descida pessoal, que será menos literária, pois os antecedentes de Marechal são Ulisses e Enéias e principalmente Dante, guiado por Virgílio, enquanto que eu fui com um modesto imigrante argelino que mal deve saber ler e escrever e que nada deve saber de Dante ou de Ibn Arabi, com seus seres ígneos, mas que me mostrou essa outra realidade. E bem, amigo, entre uma coisa e outra tento completar minha própria versão da novela, pois há pulsões que acontecem em qualquer vida, por miserável que seja, você não acha? ${ }^{14}$.

O percurso que estamos a iniciar tem a pretensão de ser, em si, um meio, uma viagem, durante a qual, mais que dizer, daremos ouvidos aos personagens, personagens literários, primeiramente, pois, consideremos que a "Síndrome de Ulisses" apareceu a mim através da literatura, de Santiago Gamboa.

Essa origem: a literatura, fez com que me questionasse sobre a "validade", digo, em termos de "aplicação", do estudo que estava prestes a empreender, já que, entre emigrantes reais e emigrantes de uma "ficção", deve haver alguma diferença, um fosso, para dizer a verdade ou não?

A partir daí, vaguei por alguns livros "literários" (refiro-me àqueles que se ocupam de pesquisar “(...) a interpretação da realidade através da representação literária ou imitação(...)" - AUERBACH, p. 486) , antes mesmo de retomar a leitura "da Síndrome" até o fim, procurando esclarecer, transpor este obstáculo que construí entre a realidade e a sua representação literária; em vão, ou melhor, foi o próprio autor, Santiago Gamboa, quem me ofereceu as melhores palavras para enxergar suas linhas e, até mesmo, atentar para a

\footnotetext{
${ }^{14}$ GAMBOA, Santiago. A síndrome de Ulisses; tradução Luis Reyes Gil. - São Paulo: Editora Planeta do Brasil, 2006. p.344-347.
}

Revista Brasileira de Direito Internacional, Curitiba, v.8, n.8, jul/dez.2008 
grande volta que precisei dar para, só então, poder reencontrá-lo. Desse vagar, devo Ihes dizer, escapou-me grande parte do conteúdo daquilo que li, por isso, serão raras as referências "diretas" aos títulos que indiquei como "referências" a estes parágrafos -

É preciso afastar-se para escrever, ir para o outro extremo do mundo, observar de longe, assim as palavras e as experiências se carregam de sentido, tudo adquire esplendor com a distância, é preciso ir embora sempre ou deixar de ser $(\ldots)^{15}$.

Visto que o narrador personagem do livro "Síndrome de Ulisses" é um jovem colombiano que fora a Paris para estudar literatura e, antes de mais nada, "tornar-se um escritor", são bastantes as questões levantadas a respeito da "realidade" a ser apresentada por um escritor. O próprio narrador faz a pergunta:

O senhor acredita que os contos podem descrever uma realidade de forma mais completa e variada que a novela? (...) Com certeza, disse ele, uma coletânea de 40 ou 50 contos pode cobrir todo o espectro geográfico, social e humano de um país e fazer o inventário de seus problemas e aspectos mais significativos, de forma mais completa e variada do que uma novela, mas é óbvio que a novela, como gênero, permite mergulhar mais fundo. Provavelmente uma novela que trate de um só problema com profundidade pode expressar melhor uma realidade do que 100 contos que tratem de forma mais superficial. Assim, a sociedade francesa do século XIX está talvez melhor representada numa novela como A educação sentimental, de Flaubert, do que nos 250 contos de Maupassant, ou, para dar um exemplo mais próximo de nós, podemos entrar mais profundamente no México graças a Pedro Páramo do que com El llano em llamas (GAMBOA, p. 338).

Não se trata de pretender "apresentar a realidade tal como ela é". O autor literário se autoriza nesta "descida à realidade"; sua pergunta pressupõe a realidade em seus escritos, sua dúvida está em relação aos graus de realidade passíveis de serem "literalizadas" e não na possibilidade de o fazer. $\mathrm{Na}$ literatura, ficção e realidade tangenciam-se paradoxalmente numa relação em que não trata, mesmo, opostos, na qual, ao permitir-se lançar-se à ficção,

${ }^{15}$ GAMBOA, Santiago. A síndrome de Ulisses; tradução Luis Reyes Gil. - São Paulo: Editora Planeta do Brasil, 2006. p.185-186.

Revista Brasileira de Direito Internacional, Curitiba, v.8, n.8, jul/dez.2008 
depara-se com a realidade; assim, ao constituir, numa ficção, uma realidade outra, "entra mais profundamente" em outra realidade.

Ao lado da questão da representação, apresentação, expressão, descrição da realidade, de "entrevista" empreendida pelo aspirante a escritor, nosso narrador personagem, a outros já escritores - escritores de todo o mundo, principalmente, latino-americanos e árabes "de Paris" -, nos são apresentadas: a literatura "do" exílio, a relação entre "a vida do escritor" e o que ele escreve; "o dever do escritor", expresso, na opinião da maioria, no "elemento político" de sua obra, para muitos autores, verdadeiro dever e o "sujeito da literatura". Os "entrevistados" dizem:

(...) A poesia e o exílio são velhos companheiros; o exílio traz com ele a tristeza do que se perdeu, o que já é em si um sentimento lírico; o exílio forçado recorre à lírica para ser denunciado; o exílio tira a lírica dos seus lugares habituais, o amor ou a gesta pátria, e lhe dá uma nova temperatura, o aproxima da realidade do mundo (...) o exílio trabalha um material poético relativamente novo, e que, claro, no seu caso, como no de tantos, esta lírica do exílio estava ligada a uma idéia do mundo, a uma visão política da história e das relações entre os seres humanos $(\ldots)^{16}$.

Eles sim podiam falar com autoridade do mundo rural pois eram naturais do lugar (...) Muitos temos regressado ao país esporadicamente e inclusive passado ali temporadas longas ou curtas, mas a fratura já se produziu, o país que visitamos é outro, não o entendemos, não podemos escrever sobre sua realidade atual, com o conhecimento, a intensidade e a confiança daqueles que não se moveram dali (...) Provavelmente há jovens escritores que estão abordando os assuntos mais cadentes das últimas décadas, com as ditaduras militares e sua queda, o exílio e a volta do exílio, a subversão e o terrorismo, o narcotráfico e a corrupção, o endividamento e a hiperinflação, com as incidências que tudo isso tem sobre o indivíduo, o ser humano particular, que no final das contas é o sujeito da literatura ${ }^{17}$.

É com o aval do autor, que me chegou da boca de seus personagens, portanto, que me autorizarei a escrever estas linhas, a partir de Gamboa, a respeito, ousemos, da realidade daquele que se encontra fora da pátria,

\footnotetext{
${ }^{16}$ GAMBOA, Santiago. A síndrome de Ulisses; tradução Luis Reyes Gil. - São Paulo: Editora Planeta do Brasil, 2006. p.316.

${ }^{17}$ GAMBOA, Santiago. A síndrome de Ulisses; tradução Luis Reyes Gil. - São Paulo: Editora Planeta do Brasil, 2006. p.338-339.
}

Revista Brasileira de Direito Internacional, Curitiba, v.8, n.8, jul/dez.2008 
realidade que, na "ficção", nos é retratada, e mais, apresentada segundo a apurada percepção do autor, dotado de autoridade e atento à estória que corresponderia a sua história.

Entre o diagnóstico conferido a Jung e diversos relatos que perpassam o livro - de "sensação de orfandade", de "solidão do imigrante" - e o estado de Odisseu durante sua "viagem de volta", há uma relação que, provavelmente, foi o que nomeou a "síndrome do imigrante" como "Síndrome de Ulisses".

A Odisseu os deuses, notoriamente, Posido, não concedem que retornasse a sua pátria, Ítaca, assim que finda sua missão em Tróia:

Polifemo, Ciclope, filho de Posido e da ninfa Toosa. Aprisiona Odisseu e alguns de seus companheiros em sua gruta e come 6 deles. Odisseu consegue fugir cegando-o e escondendo-se embaixo de uma ovelha e também por enganar o Ciclope dizendo que seu nome era "Ninguém"(outis). O Ciclope, ao chamar por ajuda dizendo que "Ninguém"o cegara, não é correspondido. É por causa disso que Posido se torna seu inimigo e atrasa em muito seu retorno a Ítaca. Polifemo já esperava esse acontecimento, pois o adivinho Télemo (IX 509) o havia predito que um humano chamado Odisseu o cegaria. ${ }^{18}$

Não são raros os relatos do sofrimento do "estrangeiro infeliz e vagante" (Canto VI, verso 206) ${ }^{19}$, “(...) Odisseu, sofredor de trabalhos” (Canto, $\mathrm{XIX}$, verso 1$)^{20}$. Como quando o que se passa ainda aprisionado pela deusa Calipso na ilha Ogígia:

Dentro da gruta não foi encontrar Odisseu de alma grande, que, como sempre, a chorar, se encontrava sentado na praia, a alma desfeita em suspiros sentidos, e prantos, e dores. Lágrimas, pois, a verter, contemplava o infecundo oceano. $(\text { Canto } \mathrm{V} \text {, verso } 81)^{21}$

$\mathrm{Na}$ ilha eólia Odisseu recebe de Éolo, o guardião dos ventos, uma sacola de couro com os ventos dentro, o que possibilita que ele e sócios de Ítaca ficassem próximos à distância da vista; porém, tendo os sócios aberto a

\footnotetext{
18 HOMERO, Odisséia; tradução Carlos Alberto Nunes. - Rio de Janeiro: Ediouro, 2001, "Apêndice" verbete "Polifemo". p.426.

${ }^{19}$ HOMERO, Odisséia; tradução Carlos Alberto Nunes. - Rio de Janeiro: Ediouro, 2001.

20 HOMERO, Odisséia; tradução Carlos Alberto Nunes. - Rio de Janeiro: Ediouro, 2001.

${ }^{21}$ HOMERO, Odisséia; tradução Carlos Alberto Nunes. - Rio de Janeiro: Ediouro, 2001.
} 
sacola, curiosos, desconfiados de que Odisseu carregava um tesouro, os ventos fazem com que retorne à ilha eólia e, quando Odisseu requisita auxílio, novamente, para à pátria voltar, responde-lhe o guardião dos ventos:

Fora, depressa, desta ilha! O mais vil dos mortais és, decerto, pois, não me é lícito aqui receber nem enviar para a pátria um indivíduo que os deuses beatos desta arte hostilizam. Vai-te! Tua volta demonstra a que ponto és por eles odiado. (Canto X, verso 72) $)^{22}$

Quase ao final da epopéia, nos é revelada a origem do nome "Odisseu" (que nos foge em "Ulisses"). Fora-Ihe conferido por seu avô, Autólico:

Filha querida e meu genro, ora o nome, que digo, lhe ponde. Vim até aqui despertando inimigos por todo o caminho, homens, não só, mas mulheres, na terra de solo fecundo. Ora Odisseu lhe chamai, 'que tem ódio'; há de ter esse nome. (Canto XIX, verso 406) ${ }^{23}$

A esses versos, o tradutor, em nota, nos esclarece que "'Odisseu', vem do verbo 'odussomai', que diz 'ter ódio'”. Esta marca "no nome” poderemos notar, também, em Édipo; tal pré-dicção, este destino do qual se tem notícia desde o batizado, é típico da tragédia e do herói gregos.

Odisseu, ainda na ilha de Ogígia, renuncia à imortalidade que a deusa Circe lhe oferecera, sob a condição de que com ela permanecesse e a tomasse por esposa, o que, consequentemente, exigiria que ele desistisse de voltar a Ítaca e aos braços de Penélope. Ainda quando as divinas Calipso ou Circe o retinham em sua casa, Odisseu não deixa que seu coração por isso se abalasse, mantém-se irredutível em sua vontade de à terra onde nascera voltar, nos diz o herói:

Bem me deteve sem sua côncava gruta a preclara Calipso, deusa entre as deusas, que ardia em desejos de que eu a esposasse. Circe, também, procurou me reter no interior de sua casa, a deusa Eéia, astuciosa, intentando fazer-se-me esposa. O coração no imo peito, porém jamais pôde abalar-me. Nada tão doce, sem dúvida, pode existir, como a pátria e os próprios pais, muito embora moremos num rico palácio,

\footnotetext{
${ }^{22}$ HOMERO, Odisséia; tradução Carlos Alberto Nunes. - Rio de Janeiro: Ediouro, 2001.

${ }^{23}$ HOMERO, Odisséia; tradução Carlos Alberto Nunes. - Rio de Janeiro: Ediouro, 2001.
} 
longe, em país estrangeiro, distante dos que nos geraram. $(\text { Canto IX, verso 29) })^{24}$

Certo sentimento de nostalgia e pesar o acompanham mesmo quando já em terra dos Feácios, certo de seu retorno a Ítaca:

(...) Odisseu, no entretanto, jamais, cessava de os olhos volver para o Sol resplendente, a suspirar pelo ocaso; anelava voltar para a pátria.

Do mesmo modo que a ceia deseja indivíduo que o dia todo no arado passou, com seus bois, a puxá-lo no alqueive, e alegremente contempla a descida do Sol para o ocaso, pois já deseja comer - ao andar sente os joelhos fraquearem: dessa maneira a Odisseu o declínio do Sol era grato. (Canto XIII, verso 28$)^{25}$

Mais do que a semelhança dos sentimentos de estar longe da pátria e todo o mal-estar que isso acarreta, o ponto que marca a passagem (de ligação) entre a Paris dos emigrantes e a Grécia, entre a "Síndrome" e Odisseu, é o inferno, a descida até o inferno, na Odisséia, o reino de Hades $^{26}$, na "Síndrome", mais explicitamente, os esgotos de Paris. As estórias se entrelaçam aí, nas descidas a outras dimensões e, também, na morte de Jung e Anticléia.

Odisseu, seguindo instruções da deusa Circe, vai até o palácio de Hades para que do vate Tirésias obtivesse "instruções a respeito da volta" (canto XXIII, verso 252). Lá, ainda encontra sua mãe, Anticléia, que lhe diz:

Não me matou no interior do palácio a frecheira veloce ${ }^{27}$, que, com seus dardos suaves, da vida, afinal, me privasse;

\footnotetext{
${ }^{24}$ HOMERO, Odisséia; tradução Carlos Alberto Nunes. - Rio de Janeiro: Ediouro, 2001.

${ }^{25}$ HOMERO, Odisséia; tradução Carlos Alberto Nunes. - Rio de Janeiro: Ediouro, 2001.

${ }^{26}$ As dimensões céu, mar e "subsolo" foram repartidas, nesta ordem, entre Zeus, Posido e Hades, quando da divisão do mundo após a guerra contra os titãs, ficando a terra, o solo, como o meio comum entre os três deuses. É bastante peculiar o fato de ter Odisseu descido ao reino de Hades e de lá retornado ainda vivo. Vernant nos diz, inclusive, que das cerimônias dos funerais e das práticas de luto tratavam mais do que de venerar as Forças superiores: "tratase, ao abrir o defunto as portas do Hades, de o fazer desaparecer para sempre do mundo terreno onde já não tem lugar." ( VERNANT, Jean-Pierre. O mito e a religião na Grécia antiga; tradução Telma Costa. - Editorial Teorema Ltda., 1991. p.48).

${ }^{27}$ A freicheira veloce é Ártemis, nos termos de Vernant: "Filha de Zeus e de Leto, irmã de Apolo, como ele detentora do arco e da lira, Ártemis assume um duplo aspecto. Ela é a Caçadora, a Corredora dos bosques, a Selvagem, a Sagitária que com seus dardos abate os animais selvagens e cujas flechas, entre os humanos, às vezes atingem as mulheres, dandoIhes morte súbita." (VERNANT, Jean-Pierre. A morte nos olhos: figuração do Outro na Grécia antiga. tradução Clóvis Marques. - Rio de Janeiro, $2^{2}$ ed.: Jorge Zahar Editor, 1991. p.15)
}

Revista Brasileira de Direito Internacional, Curitiba, v.8, n.8, jul/dez.2008 
Nem foi, tampouco, doença que sói produzir nos humanos definhamento terrível, e a força dos membros apaga; mas os cuidados, ilustre Odisseu, por tua causa, e a saudade, como a ternura que a mim dedicavas, tiraram-me a vida. (canto XI , verso 198$)^{28}$

E mais, Odisseu e Penélope, Jung e Min Lin formam os casais "separados", cuja volta, aquela volta que representa a chegada de viagem, o retorno, torna ou tornaria a unir.

O empréstimo ou a tomada do nome de um herói de tragédia grega não é novidade. Simone Perelson, em análise sobre "O desejo de Antígona", nos faz compreender que na tragédia o herói é quem age, porque não tem escolha, e não há para ele escolha, pois seu destino o precede e é a ele tanto mais estranho quanto mais lhe marca e o constitui no que lhe há de mais íntimo e desconhecido ${ }^{29}$.

O que faz o herói, então, é a ação de não renunciar a nada dessa determinação que o ultrapassa, a qual, ao mesmo tempo que o sujeita, os presságios que o acompanham, como o seu nome, o fazem sujeito; sujeito, cuja "responsabilidade fundamental está em incorrer, como nos dirá Lacan, à castração"30 - e aqui podemos conferir a centralidade do Complexo de Édipo na teoria psicanalítica, na medida em que se trata, essencialmente da castração ${ }^{31}$ com que o sujeito se depara :

\footnotetext{
${ }^{28}$ HOMERO, Odisséia; tradução Carlos Alberto Nunes. - Rio de Janeiro: Ediouro, 2001.

${ }^{29}$ A este respeito, Clemente Rosset: "a idéia de que o que está mais próximo é também o que está mais longe, o mais conhecido é o mais desconhecido, o mais familiar, o mais estranho, é um tema que alimenta ao mesmo tempo a tragédia grega e o pensamento psicanalítico". (ROSSET, C. Lógica do Pior. Espaço e Tempo, Rio de Janeiro, 1989, p.78 Apud PERELSON, Simone. A dimensão trágica do desejo. P. 49) e Zizek: "o que é 'em nós mais do que nós', um corpo estranho no próprio cerne do sujeito." (ZIZEK, S. Le Plus Sublime dês Hysteriques Hegel Passe. Point Hors Ligne, France, 1988, p. 207. Apud PERELSON, Simone. A dimensão trágica do desejo. - Rio de Janeiro: Livraria e Editora Revinter Ltda, 1994.p. 49).

30 PERELSON, Simone. A dimensão trágica do desejo. - Rio de Janeiro: Livraria e Editora Revinter Ltda, 1994.p.48.

${ }^{31}$ Não seria demais, ainda que em nota de rodapé, dedicar algumas linhas ao esclarecimento destes termos: castração e interdição, sobre eles, a autora:

Aquilo que constitui no homem o sujeito é a castração. Mas é importante não confundir castração com interdição, pois aquilo de que se trata em psicanálise, aquilo que marca o homem com uma responsabilidade fundamental chamada sujeito, não é a interdição mas sim a castração (...) De que forma distinguem-se a submissão ao interdito e a incorrência à castração? Enquanto a primeira significa a aceitação da proibição de uma possibilidade, a segunda consiste na submissão à impossibilidade da opção (PERELSON, Simone. A dimensão trágica do desejo. - Rio de Janeiro: Livraria e Editora Revinter Ltda, 1994. p.48).
}

Revista Brasileira de Direito Internacional, Curitiba, v.8, n.8, jul/dez.2008 
Tal como todos os heróis, ela está sempre fora dos limites. Transgredindo-os, é levada a uma zona limite entre a vida e a morte. Sua vida é invadida pela morte; neste extremo, nesta zona limite, ela permanece solitária, isolada e, até o fim, implacável, não conhecerá nem temor nem piedade. ${ }^{32}$

Antígona sabe que, mesmo sem compreender a sua ação, mesmo sem senti-la como uma opção, ela é absolutamente necessária. Antígona sabe que não poderia agir de outra forma. ${ }^{33}$

É nesse sentido, por exemplo, que o herói Édipo representa o Complexo que concentra as bases da Psicanálise, ao menos da Psicanálise pensada por Freud. Em seus escritos, resumidamente, o complexo de Édipo consiste na primeira escolha objetal realizada pelo sujeito, o qual se vê impossibilitado de satisfazer-se através da realização de tal escolha, visto que se trata do desejo de incesto, dirigido ao pai e/ou ${ }^{34}$ à mãe. Essa impossibilidade é apresentada ao sujeito pelo temor da castração, o que, idealmente, fará com que o sujeito "dissolva" o complexo da seguinte maneira: após sua escolha objetal, procederá à introjeção desse objeto através da identificação, ou seja, o Ego, diante da interdição, incorpora o objeto para que, então, ele mesmo passe a ser seu objeto, passível de ser alvo de seu próprio investimento libidinal - a esse movimento: escolha objetal - identificaçãoinvestimento, Freud denominou "narcisismo secundário". E é esse mesmo mecanismo o responsável pela formação do Super-Ego, conhecido como "O Herdeiro do Complexo de Édipo" e que, embora seja fruto de uma identificação de um objeto externo, está, qualitativamente, mais próximo ao Id do que do Ego; afinal, a dita escolha do objeto provém, essencialmente, do Id. O Super-

\footnotetext{
${ }^{32}$ PERELSON, Simone. A dimensão trágica do desejo. - Rio de Janeiro: Livraria e Editora Revinter Ltda, 1994. p.28.

${ }^{33}$ PERELSON, Simone. A dimensão trágica do desejo. - Rio de Janeiro: Livraria e Editora Revinter Ltda, 1994. p.48.

${ }^{34}$ Não é arbitrária a escolha tanto de "e" quanto de "ou" a fim de especificar a direção do desejo de incesto de que trata o Complexo de Édipo, pois tem-se em conta "a bissexualidade constitucional de cada indivíduo" ( FREUD, S. O Ego e o Superego (1923) Edição Standard Brasileira das Obras Psicológicas completas de S. Freud. Rio de Janeiro, Ed. Imago. Vol. XIX. p.46) - "Isso equivale a dizer que um menino não tem simplesmente uma atitude ambivalente para com o pai e uma afetuosa pela mãe, mas que, ao mesmo tempo, também se comporta como uma menina e apresenta uma atitude afetuosa feminina para com o pai e um ciúme e uma hostilidade correspondentes em relação à mãe." ( FREUD, S. O Ego e o Superego (1923) Edição Standard Brasileira das Obras Psicológicas completas de S. Freud. Rio de Janeiro, Ed. Imago. Vol. XIX. p. 47-48)
}

Revista Brasileira de Direito Internacional, Curitiba, v.8, n.8, jul/dez.2008 
Ego, pode-se dizer, é o resultado do embate entre a imposição do Id em satisfazer seus desejos e as limitações a essa satisfação apresentadas ao Ego pelo "mundo externo". Por isso, o Super-Ego é a instância que tornará possível a satisfação, pois é o que irá conciliar pulsão - possibilidade de satisfação, sem que, para tanto, o Ego tenha de submeter-se à castração:

O ideal do ego, portanto, é o herdeiro do complexo de Édipo, e, assim, constitui também a expressão dos mais poderosos impulsos e das mais importantes vicissitudes libidinais do id. Erigindo esse ideal do ego, o ego dominou o complexo de Édipo e, ao mesmo tempo, colocou-se em sujeição ao id. Enquanto que o ego é essencialmente o representante do mundo externo, da realidade, o superego coloca-se, em contrates com ele, como representante do mundo interno, do id. Os conflitos entre o ego e o ideal, como agora estamos preparados para descobrir, em última análise refletirão o contrates entre o que é real e o que é psíquico, entre o mundo externo e o mundo interno. ${ }^{35}$

A Afirmação de Freud de que o Super-Ego é, ao contrário do que usualmente se pensa das instâncias cuja função é, justamente, a de regulação, de conciliação, o que há de mais próximo ao Id, às pulsões, assim, o SuperEgo se produz do material pulsional e não em contrapartida ou em oposição a esse material, é o ld sua condição para sua formação.

Dito isso, a questão que nos leva a esboçar algum tipo de consideração é: afinal, por que o nome "Édipo" foi escolhido por Freud para esse mecanismo psíquico tão precioso à Psicanálise?

Para procurar trazer alguma luz a essa questão, nada mais coerente do que voltar ao "Édipo Rei", de Sófocles.

A nossa primeira impressão, após ler a tragédia, foi a de que Édipo sabia, desde o início, qual seria seu "destino", pois fora alertado pelos oráculos sobre a desgraça que o esperava. No entanto, ele nega tal predestinação a ponto de fugir do convívio dos seus "pais", para que as previsões quanto ao seu destino não se concretizassem. No entanto, foi querendo, justamente, fugir que ele se deparou com o profetizado pelos oráculos.

\footnotetext{
${ }^{35}$ FREUD, S. O Ego e o Superego (1923) Edição Standard Brasileira das Obras Psicológicas completas de S. Freud. Rio de Janeiro, Ed. Imago. Vol. XIX. p. 51.
}

Revista Brasileira de Direito Internacional, Curitiba, v.8, n.8, jul/dez.2008 
Aqui podemos arriscar um diálogo entre a Tragédia Grega e a Psicanálise, na medida em que, tanto o complexo quanto o destino de Édipo na Tragédia, são, de alguma maneira, "inatos", de certa forma, imanentes ao ser, irrenunciáveis, enquanto fator constitutivo do indivíduo, o qual, querendo ou não, passará por ele.

Vários pontos sobre a tentativa deste diálogo encontram-se presentes, também, no artigo de Ana Vicente Azevedo: "Entre Túche e Autómaton: O Próprio Nome de Édipo", em que a autora destaca, inclusive, algumas semelhanças entre o processo estabelecido pela análise e a narrativa da Tragédia, que, essencialmente, estaria no questionamento trazido pelo sujeito no sentido de descobrir a sua origem. O Édipo da Tragédia empreende uma investigação a respeito de sua identidade, ele quer saber "quem ele é" / "quem sou eu?" e, ao longo da narração, interroga seus interlocutores a esse respeito, até chegar à confirmação de seu destino.

O que nos pareceu curioso é, justamente, a avidez com que Édipo provoca a confirmação "do outro" para o que ele, de certa maneira, já sabia que era a verdade, pois isso já the havia sido revelado pelos oráculos. Aqui, a nosso ver, há alguma semelhança com a Psicanálise, aliás, com uma das primeiras coisas que aprendemos sobre ela, a saber: que o analista não sabe sobre seu paciente, quem sabe sobre ele, é ele mesmo. Ora, o Édipo da Tragédia, por mais que "os outros" tenham lhe dito qual a sua origem desde muito tempo... ele, verdadeiramente, não aceitava o que lhe fora dito, na tentativa de clarear o que tentei dizer: por mais que a verdade estivesse a todo tempo diante de seus olhos, ela não era vista por ele, que era incapaz de identificar-se com ela. Foi só apenas através da "análise" perpassada por toda a tragédia que, ao final, ele consegue enxergar - e, então, tudo fica claro e the faz sentido - que, afinal, as pré-dicções haviam se concretizado por seus próprios atos. O mais intrigante é que, justamente quando ele se torna capaz de ver, tal visão the é a tal ponto insuportável que ele mesmo arranca seus olhos para não ver a tragédia que agora ele podia reconhecer como sua.

Há um traço paradoxal nisso tudo, visto que, conforme a afirmação do "saber sobre si", a que acima nos referimos, ou seja, "que o analista não sabe 
sobre seu paciente, quem sabe sobre ele, é ele mesmo", ao mesmo tempo em que é o sujeito, exclusivamente, o possuidor de tal conhecimento, no caso do Édipo, foi-lhe necessário um interlocutor para que ele pudesse, finalmente, "ver". Notável é que "o interlocutor" sempre esteve presente na vida do Édipo e queremos destacar, aqui, os oráculos; entretanto, aquele não aceitava o que estes lhe afirmavam, o discurso do interlocutor só fez sentido para ele quando, ele mesmo, a partir de uma questão - "quem matou Laio?" -, procura respostas neste diálogo.

Quanto ao nome "Édipo", sua etimologia merece, também, alguma atenção. Quer dizer "pés inchados", nome a ele conferido pelos pastores de Citeron e não por seus genitores, porque o menino tinha os pés atados quando foi entregue aos pastores, o que até a vida adulta marcou seu corpo; mais uma vez, os oráculos, as seqüelas e seu próprio nome não bastaram para que Édipo conhecesse, verdadeiramente, de sua origem.

Não a título de conclusão, mas apenas a fim de sintetizar algumas das impressões que nos surgiram quando da tentativa de dialogar com o Édipo de Freud e com o Édipo de Sófocles, gostaríamos de acrescentar que foi muito grande a nossa surpresa por encontrar, pode-se assim dizer, tantas semelhanças entre ambos; em poder observar, porque não dizer, muitas semelhanças, também, no que, a princípio, nos parecia mais uma arbitrariedade do que uma eleição, agora, aparentemente, muito bem pensada por Freud, o que nos forneceu alguns instrumentos, até, para ver mais claramente o Complexo, posto que a Tragédia não deixa de ser um exemplo bastante ilustrativo.

O que nos pareceu mais surpreendente disso tudo foi a repetição das narrativas, tanto em relação às semelhanças entre Tragédia e o Complexo, quanto na própria Investigação e na Análise que se mostraram na tragédia e podem ser observadas durante o processo de análise. Quando pensamos em repetição, a idéia que nos vem é a expressa por "lá onde isso era, devo eu vir a estar", na qual é possível identificar este ciclo, que tende, inevitavelmente, a levar o sujeito às experiências que o constituíram como tal, até que ele seja capaz, ou não, de libertar-se de tal experiência, não no sentido de negá-la, mas 
no sentido de "Recordar, Repetir e Elaborar", quando, então, o sujeito tomará consciência de quem ele é ${ }^{36}$.

A constituição do ego, desde a Psicanálise, está neste passe entre o interno e o externo, entre o individual e o social e, à constituição, acrescente-se construção, visto que tratamos de um processo, em "etapas", que podem, mesmo, ser evidenciadas nos termos utilizados por Freud a dizer dessas passagens do sujeito. Assim, seguindo o que se esboçou no Complexo de Édipo, Freud, a respeito da diferença entre Ideal do ego e narcisismo:

O desenvolvimento do ego consiste num afastamento do narcisismo primário e dá margem a uma vigorosa tentativa de recuperação desse estado. Esse afastamento é ocasionado pelo deslocamento da libido em direção a um ideal do ego imposto de fora, sendo a satisfação provocada pela realização desse ideal. ${ }^{37}$

E ainda:

O que ele projeta diante de si como sendo seu ideal é o substituto do narcisismo perdido de sua infância na qual ele era o seu próprio ideal. $^{38}$

Nessa linha de pensamento, portanto, o narcisismo seria um substituto ao ideal do ego, na medida em que estabelece na vida "adulta" a busca pelo

\footnotetext{
${ }^{36}$ A respeito do "saber sobre si", gostaria de citar dois pensadores Lacan e Vernant. Lacan estabelece o estatuto do desejo nos termos do "só sei que nada sei" de Sócrates e Vernant esclarece a diferença entre o "conhece-te a ti mesmo" mítico e filosófico. Vejamos:

"Para o oráculo de Delfos, 'Conhece-te a ti próprio' significa: sabe que não és deus e não cometas o erro de querer tornar-te deus. Para o Sócrates de Platão, que retoma por sua vez a fórmula, quer dizer: conhece o deus que, em ti, és tu próprio. Esforça-te por te tornares, tanto quanto possível, semelhante do deus." (VERNANT,Jean-Pierre. O Mito e a Religião na Grécia Antiga. ; tradução Telma Costa. - Editorial Teorema Ltda., 1991. p. 88)

"Eu disse que o campo freudiano da prática analítica permanecia na dependência de certo desejo original que tem sempre papel ambíguo, mas prevalecente, na transmissão da psicanálise. O problema desse desejo não é psicológico, tanto quanto não o é aquele, não resolvido, do desejo de Sócrates. Há toda uma temática que tem a ver com o estatuto do sujeito quando Sócrates formula nada saber, a não ser o que diz respeito ao desejo. O desejo não é posto por Sócrates em posição de subjetividade original, mas em posição de objeto. Muito bem! É também do desejo como objeto que se trata em Freud." (LACAN, Jacques. $O$ Seminário, Livro 11. Os Quatro Conceitos Fundamentais da Psicanálise (1964). Zahar, Rio de Janeiro, 1985. p. 20)

${ }_{37}$ FREUD, S. Sobre o Narcisismo: Uma Introdução (1914). Edição Standard Brasileira das Obras Completas de S. Freud. RJ, Ed. Imago. Vol. XIV, 1976. p. 117

${ }^{38}$ FREUD, S. Sobre o Narcisismo: Uma Introdução (1914). Edição Standard Brasileira das Obras Completas de S. Freud. RJ, Ed. Imago. Vol. XIV, 1976. p.111.
}

Revista Brasileira de Direito Internacional, Curitiba, v.8, n.8, jul/dez.2008 
sentimento de satisfação plena experimentado pelo ideal do ego na fase do narcisismo primário. Resumidamente: na "primeira" infância há uma identidade entre o ego real e seu ideal, em uma situação de satisfação plena, de perfeição, porque o sujeito não diferencia a realidade "do mundo" de sua subjetividade, durante seu desenvolvimento, o mesmo sujeito percebe que há uma realidade que, inevitavelmente, irá barrar sua satisfação plena, mesmo assim,

(...) ele não está disposto a renunciar à perfeição narcisista de sua infância; e quando, ao crescer, se vê perturbado pelas admoestações de terceiros e pelo despertar de seu próprio julgamento crítico, de modo a não mais poder reter aquela perfeição, procura recuperá-la sob a nova forma de um ego ideal. ${ }^{39}$

Há que se ressaltar que tal constituição, suas etapas e progressos, não seguem uma ordem linear ou mesmo pré-determinada, em que a nova etapa alcançada supera a passada de maneira irreversível; pelo contrário, elas coexistem, se confundem, se sobrepõem.

Retomando os ditos de Freud, no sentido de que o ideal do ego "contém o germe do qual todas as religiões evolveram", ele introduzirá a "origem" do sentimento de culpa: saldo entre a exigência do ideal do ego e as realizações "concretas" do ego - "A tensão entre as exigências da consciência e os desempenhos concretos do ego é experimentada como sentimento de culpa" - e a "transição" que se segue a partir da família:

À medida que uma criança cresce, o papel do pai é exercido pelos professores e outras pessoas colocadas em posição de autoridade; suas injunções e proibições permanecem poderosas no ideal do ego e continuam, sob a forma de consciência (conscience), a exercer a censura moral. ${ }^{40}$

Neste ponto, ser-nos-á pertinente introduzir as observações de Jean Claude Rouchy a respeito, justamente, dessa transição, por ele enunciada em

\footnotetext{
${ }^{39}$ FREUD, S. Sobre o Narcisismo: Uma Introdução (1914). Edição Standard Brasileira das Obras Completas de S. Freud. RJ, Ed. Imago. Vol. XIV, 1976. p.111.

${ }^{40}$ FREUD, S. O Ego e o Superego (1923) Edição Standard Brasileira das Obras Psicológicas completas de S. Freud. Rio de Janeiro, Ed. Imago. Vol. XIX. p.52.
}

Revista Brasileira de Direito Internacional, Curitiba, v.8, n.8, jul/dez.2008 
termos de grupos de pertencimento primário e secundário ${ }^{41}$, segundo Rouchy "internalizados no indivíduo" ${ }^{42}$. Processo (de transição) em que são a continuidade e descontinuidade tais os grupos "um dos fatores determinantes da estruturação da identidade e seus avatares"43. A individuação, neste sentido, procede daquilo que é comum, que é compartilhado - "Existe, no plano grupal, uma base comum partilhada, um apoio cultural partilhado do qual procede a individuação." 44

Rouchy ainda destaca a migração como fenômeno capaz destacar as rupturas (entre o familiar e o social) pelas quais o sujeito constituído e em constituição é suscetível a experimentar durante o processo de que viemos falando. Entre o familiar e o social, entre narcisismo, ideal do eu, a identificação

${ }^{41}$ Pensamos ser possível a aproximação entre os conceitos de grupos de pertencimento primário e secundário, respectivamente, ao que Freud denominara "papel do pai", posteriormente "substituído" "pelos professores e outras pessoas colocadas em posição de autoridade" (FREUD, S. O Ego e o Superego (1923) Edição Standard Brasileira das Obras Psicológicas completas de S. Freud. Rio de Janeiro, Ed. Imago. Vol. XIX. p. 52). A seguir, os conceitos tal qual formulados por Rouchy:

O grupo de pertencimento primário é a matriz da identidade cultural de grupo; é a base partilhada da qual procede a individuação. É nesse sentido que podemos compreender o pensamento de E. T. Hall, quando ele afirma que a cultura traça a linha que separa o interior do exterior. A experiência é partilhada, inicialmente, na indiferenciação, em uma unidade em que a relação de objeto ainda não existe e só vai aparecer progressivamente. Essa base cultural do eu determina os limites do indivíduo e do grupo, do eu e do não eu, do interior e do exterior, do "dentro" e do "fora", do imaginário e do real (...) As funções psíquica mostrariam, dessa forma, o traço das incorporações culturais do grupo de pertencimento primário de forma que a subjetividade só ganha sentido na e pela intersubjetividade (...)."ROUCHY, Jean Claude. Identificação e grupos de pertencimento. In Cenários sociais e abordagem clínica Orgs.: ARAÚJO, José Newton Garcia de e CARRETEIRO, Teresa Cristina. p. 123-139. Ed. Escuta. p. 131).

Nos grupos de pertencimento secundário é a diferença que organiza as trocas" (...) De fato, trata-se de grupos instituídos dentro dos quais os indivíduos estão reunidos. Eles são, nesse sentido, bastante diferentes dos grupos primários, pois sua constituição pressupõe que a individuação seja suficientemente avançada para que haja tanto uma relação objeto quanto de indivíduo a indivíduo (...) Os grupos secundários completam a interiorização cultural e concretizam a apreensão do espaço e do tempo: eles têm, pois, uma função de socialização e de interiorização de normas e de valores. (ROUCHY, Jean Claude. Identificação e grupos de pertencimento. In Cenários sociais e abordagem clínica Orgs.: ARAÚJO, José Newton Garcia de e CARRETEIRO, Teresa Cristina. p. 123-139. Ed. Escuta. p.132).

${ }^{42}$ ROUCHY, Jean Claude. Identificação e grupos de pertencimento. In Cenários sociais e abordagem clínica Orgs.: ARAÚJO, José Newton Garcia de e CARRETEIRO, Teresa Cristina. p. 123-139. Ed. Escuta. p. 130.

${ }^{43}$ ROUCHY, Jean Claude. Identificação e grupos de pertencimento. In Cenários sociais e abordagem clínica Orgs.: ARAÚJO, José Newton Garcia de e CARRETEIRO, Teresa Cristina. p. 123-139. Ed. Escuta. p.134.

${ }^{44}$ ROUCHY, Jean Claude. Identificação e grupos de pertencimento. In Cenários sociais e abordagem clínica Orgs.: ARAÚJO, José Newton Garcia de e CARRETEIRO, Teresa Cristina. p. 123-139. Ed. Escuta. p. 131.

Revista Brasileira de Direito Internacional, Curitiba, v.8, n.8, jul/dez.2008 
e a escolha objetal, há que se falar, novamente, em continuidade e descontinuidade ${ }^{45}$, nas diferenças que podem ser vivenciadas quando da passagem por estes meios. Assim:

A migração, do exterior e do interior, dá uma visão ampliada de fenômenos que estão sempre presentes na vida social, dado que o grupo de pertencimento primário é um dos elementos do tecido social. No choque de culturas, o grupo de pertencimento primário pode se manter ou se fragmentar. Se ele não é mais "continente", constatamos não somente a perda de bases culturais partilhadas, uma confusão na diferença dos sexos e das relações genealógicas, uma carência da função do eu auxiliar protetor da mãe, dos pais que dão um sentido e organizam o universo dos signos e permitem o acesso à simbolização (...) como, também, a perda da origem que assegura o lugar na linhagem (da filiação à paternidade/maternidade) e a perenidade do grupo primário. $\mathrm{O}$ devir está apoiado no passado. ${ }^{46}$

A trajetória que percorremos até aqui nada mais foi do que a construção de uma ponte, uma ponte que fosse capaz de nos possibilitar a travessia que o nome "Ulisses" nos suscitara, por assim dizer, entre Gamboa e Homero. No entanto, tal esforço não foi suficiente, e arriscamos dizer que esforço algum o seria, na medida em que, ao final dessa ponte, a morte nos espera, eis o motivo de nossa afirmação. Em se tratando da morte, da descida ao reino dos mortos empreendida pelos "Ulisses", nossa aposta é a de que a ponte é insuscetível de ser "terminada", há um limite ao qual se pode chegar, uma aproximação limite, aproximação, no sentido de tangenciar o limite, o "fim da linha", entre o conceito, entre a ficção, entre o representável e a realidade, entre os quais, a hiância, o buraco, o intervalo, o não-contínuo: no limite, o salto $^{47}$.

${ }^{45}$ ROUCHY, Jean Claude. Identificação e grupos de pertencimento. In Cenários sociais e abordagem clínica Orgs.: ARAÚJO, José Newton Garcia de e CARRETEIRO, Teresa Cristina. p. 123-139. Ed. Escuta. p.134.

${ }^{46}$ ROUCHY, Jean Claude. Identificação e grupos de pertencimento. In Cenários sociais e abordagem clínica Orgs.: ARAÚJO, José Newton Garcia de e CARRETEIRO, Teresa Cristina. p. 123-139. Ed. Escuta. p.. 134-135)

${ }^{47}$ É a partir da pergunta - O que é o Inconsciente? - que Lacan nos recusa o conceito, recusase a dizer o que é o Inconsciente. Ora, não há coisa mais particular à Psicanálise, nos termos de LACAN, "outra coisa senão a recusa do conceito" (LACAN, Jacques. O Seminário, Livro 11. Os Quatro Conceitos Fundamentais da Psicanálise (1964). Zahar, Rio de Janeiro, 1985. p. 24.),

Revista Brasileira de Direito Internacional, Curitiba, v.8, n.8, jul/dez.2008 
$\mathrm{O}$ que teria pensado ou lembrado Jung enquanto cruzava o ar em direção ao chão? Talvez nos olhos de Min Lin, que não se atreveu a enfrentar, ou nos da sua mãe, a mulher que o trouxe ao mundo do qual estava para ir embora e onde só conseguira sofrer. Quis imaginá-lo no parapeito da janela, observando as luzes da cidade. Ninguém se atira imediatamente. Ao ver aquelas luzes devia ter sentido raiva ou rancor, ou inclusive medo, e depois a pancada, o impacto final, tão duro como o modo em que viveu, sempre na defensiva, às vezes tentando se recuperar, como aqueles jogadores que passam dias e noites nos cassinos até perder tudo, assim aconteceu com Jung na vida, e então só conseguiu ir embora, deixar no meio da rua, sem nenhum pudor, um corpo sangrando e flagelado. ${ }^{48}$

\section{REFERÊNCIAS}

AUERBACH, Erich. Mimesis: a representação da realidade na literatura ocidental - A cicatriz de Ulisses p. 1-20 e Epílogo p. 486-489. - São Paulo: Editora da Universidade de S. Paulo, Editora Perspectiva, 1971.

. Introdução aos estudos literários. Capítulo: As pesquisas literárias, p. 25-42; tradução José Paulo Paes. - São Paulo: Editora Cultrix.

AZEVEDO, Ana Vicente. Entre Túche e Autómaton: O Próprio Nome de Édipo. Publicado em 1999. Disponível em <

http://www.interseccaopsicanalitica.com.br/art003.htm>

FREUD, S. Sobre o Narcisismo: Uma Introdução (1914). Edição Standard Brasileira das Obras Completas de S. Freud. RJ, Ed. Imago. Vol. XIV, 1976.

.O Ego e o Superego (1923) Edição Standard Brasileira das Obras Psicológicas completas de S. Freud. Rio de Janeiro, Ed. Imago. Vol. XIX.

. A Dissolução do Complexo de Édipo (1924). Edição Standard Brasileira das Obras Completas de S. Freud. RJ, Ed. Imago. Vol. XIX, 1976.

postura que corresponde à abordagem do inconsciente, insuscetível de ser contido por uma definição, em um conceito, em decorrência do que LACAN lança mão da aproximação:

"(...) nossa concepção do conceito implica ser este sempre estabelecido numa aproximação que não deixa de ter relação com o que nos impõe, como forma, o cálculo infinitesimal. Se o conceito se modela, com efeito, por uma aproximação da realidade que ele foi feito para apreender, só por um salto, por uma passagem ao limite, é que ele chega a se realizar." (LACAN, Jacques. O Seminário, Livro 11. Os Quatro Conceitos Fundamentais da Psicanálise (1964). Zahar, Rio de Janeiro, 1985. p. 25)

Assim, tanto a teoria quanto a prática da Psicanálise lidam constantemente com o limite, "não o não-conceito, mas o conceito da falta" (LACAN, Jacques. O Seminário, Livro 11. Os Quatro Conceitos Fundamentais da Psicanálise (1964). Zahar, Rio de Janeiro, 1985. p. 30) com o real.

${ }^{48}$ GAMBOA, Santiago. A síndrome de Ulisses; tradução Luis Reyes Gil. - São Paulo: Editora Planeta do Brasil, 2006. p.371.

Revista Brasileira de Direito Internacional, Curitiba, v.8, n.8, jul/dez.2008 
GAMBOA, Santiago. A síndrome de Ulisses; tradução Luis Reyes Gil. - São Paulo: Editora Planeta do Brasil, 2006.

GERBASE, Jairo. Complexo de Édipo: paradigma da psicanálise. Disponível em < http://pepsic.bvs-psi.org. br/scielo. php?script=sci_arttext\&pid=S151994792004000100008\&lng=pt\&nrm=iso >

HOMERO. Odisséia; tradução Carlos Alberto Nunes. - Rio de Janeiro: Ediouro, 2001.

LACAN, J. O Seminário, Livro 11. Os Quatro Conceitos Fundamentais da Psicanálise (1964). Zahar, Rio de Janeiro, 1985.

LOPARIC, Z. Winnicott. Uma Psicanálise Não-Edipiana. Disponível em < http://www2.uol.com.br/percurso/main/pcs17/p17_14.htm >

NICOLAU, Adriana Bisi. Abuso Sexual na Adolescência - Discussões teóricas e possibilidades terapêuticas. Disponível em<

http://www.rubedo.psc.br/artigosb/abusosex.htm >

PERELSON, Simone. A dimensão trágica do desejo. - Rio de Janeiro: Livraria e Editora Revinter Ltda, 1994.

PESSOA, Fernando. Mensagem; organização Fernando Cabral Martins. - São Paulo: Companhia das Letras, 1998.

ROSSET, C. Lógica do Pior. Espaço e Tempo, Rio de Janeiro, 1989, p. 78 Apud PERELSON, Simone. A dimensão trágica do desejo. - Rio de Janeiro: Livraria e Editora Revinter Ltda, 1994.p. 49.

ROUCHY, Jean Claude. Identificação e grupos de pertencimento. In Cenários sociais e abordagem clínica Orgs.: ARAUJO, José Newton Garcia de e CARRETEIRO, Teresa Cristina. p. 123-139. Ed. Escuta.

VERNANT, Jean-Pierre. A morte nos olhos: figuração do Outro na Grécia antiga; tradução Clóvis Marques. - Rio de Janeiro, $2^{a}$ ed.: Jorge Zahar Editor, 1991.

Revista Brasileira de Direito Internacional, Curitiba, v.8, n.8, jul/dez.2008 
O mito e a religião na Grécia antiga; tradução Telma Costa. Editorial Teorema Ltda., 1991.

ZIZEK, S. Le Plus Sublime dês Hysteriques - Hegel Passe. Point Hors Ligne, France, 1988, p. 207. Apud PERELSON, Simone. A dimensão trágica do desejo. - Rio de Janeiro: Livraria e Editora Revinter Ltda, 1994. p. 49.

Revista Brasileira de Direito Internacional, Curitiba, v.8, n.8, jul/dez.2008 